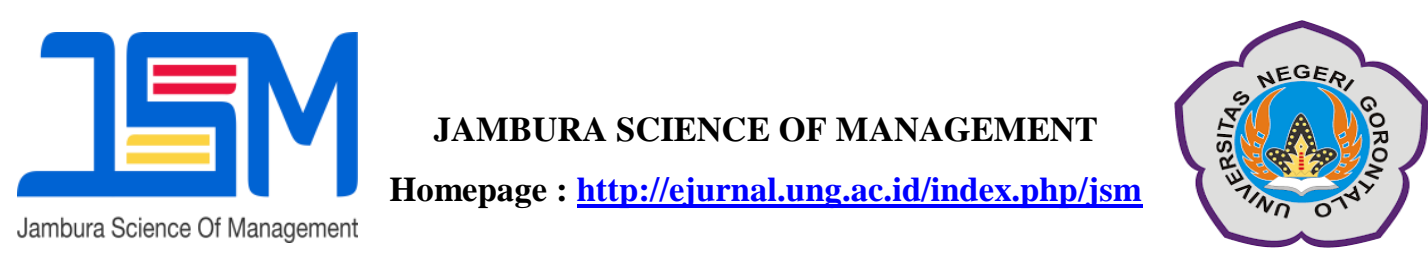

\title{
How Does The Relationship Between Lifestyle With Consumer Decisions In Buying Motorbikes?
}

\author{
Hapsawati Taan ${ }^{1}$, Djoko Lesmana Radji ${ }^{2}$ \\ ${ }^{1,2}$ Faculty of Economics, Gorontalo State University \\ E-Mail: hapsataan@yahoo.co.id
}

\begin{abstract}
:
This study aims to test and analyze the influence of lifestyle on purchasing decisions of Yamaha ZR vega motorcycles at PT. Hasjrat Abadi Gorontalo. This research uses quantitative methods. Respondents are they who ever buy vega zr motors for three last years of 2016, 2017, 2018 that all over 97 people. Data were analyzed using simple regression analysis. The results showed that lifestyle variables had a significant effect on purchasing decisions at PT Hasjrat Abadi Gorontalo City. Suggestions should the leadership of PT Hasjrat Abadi Kota Gorontalo pay more attention to consumer lifestyles, for example, from various motor designs, motorcycle brand images and promotions. In addition, it is expected to pay more attention to the selection of inadequate alternatives and the lack of products with the latest models.
\end{abstract}

\section{Keywords: Lifestyle; Purchasing Decisions; Motorbikes}

The development of the automotive world is currently able to attract attention. The need for motorbikes is part of the consumer lifestyle. The enthusiasm of a part of the community towards Yamaha motorbikes is one of the features of this phenomenon. The motorcycle industry in Indonesia can be seen from a number of brands / brands of motorcycles which are the world's largest manufacturers that have many users, namely Honda, Yamaha, Suzuki and Kawasaki. The high demand for motorbikes in Indonesia is mainly because motorbikes are a cheap, practical and efficient means of transportation. The rapid demand and public purchasing power of motorcycles in Indonesia is also supported by the emergence of convenience in obtaining motorbikes through the provision of motorcycle loans.

Consumer behavior is a very important phenomenon in corporate marketing activities, namely consumer behavior in making purchases. Studying and analyzing consumer behavior in purchasing decisions is an important basic thing, because with a good basic knowledge of consumer behavior, companies can better know what consumers want themselves, especially in 
relation to consumer purchasing decisions that are always changing. Facing the reality, sellers are required to develop active marketing policies and always follow the development of the economy, technology, needs and lifestyle of the people. Companies must develop information and knowledge about the product sales strategy.

Widjaja (2014: 103) stated that consumers are motivated in shopping because of the element and drive for needs that arise because of the lifestyle. There are 4 categories that become motives in the buying process by consumers in order to fulfill and desire the consumers themselves so that they are satisfied with what consumers have got because of lifestyle, namely the purchase of useful products, self-indulgence, luxury lifestyle and luxury hajrat.

Some research on lifestyle found that lifestyle as a factor that is closer to reflecting interests and value values of consumers who continue to experience change and ultimately that value will affect their behavior. According to Kotler (2009: 105 ) as for factors that influence consumer purchasing decisions consist of age and life cycle stages, work and economic environment, lifestyle, personality and self-concept. The choice of product is greatly influenced by one's economic situation.

According to Almi (2012: 9) that the lifestyle to the purchase decision in his research states that the purchasing decision on Yamaha motorcycles is positively and significantly influenced by lifestyle. This study the presenter tried to apply the research to PT Hasjrat Abadi Gorontalo City together to discuss the influence of lifestyle on purchasing decisions, but in this study there were also differences about promotion and product quality. Lifestyle is part of human secondary needs that can change depending on the age or desire of someone to change his lifestyle.

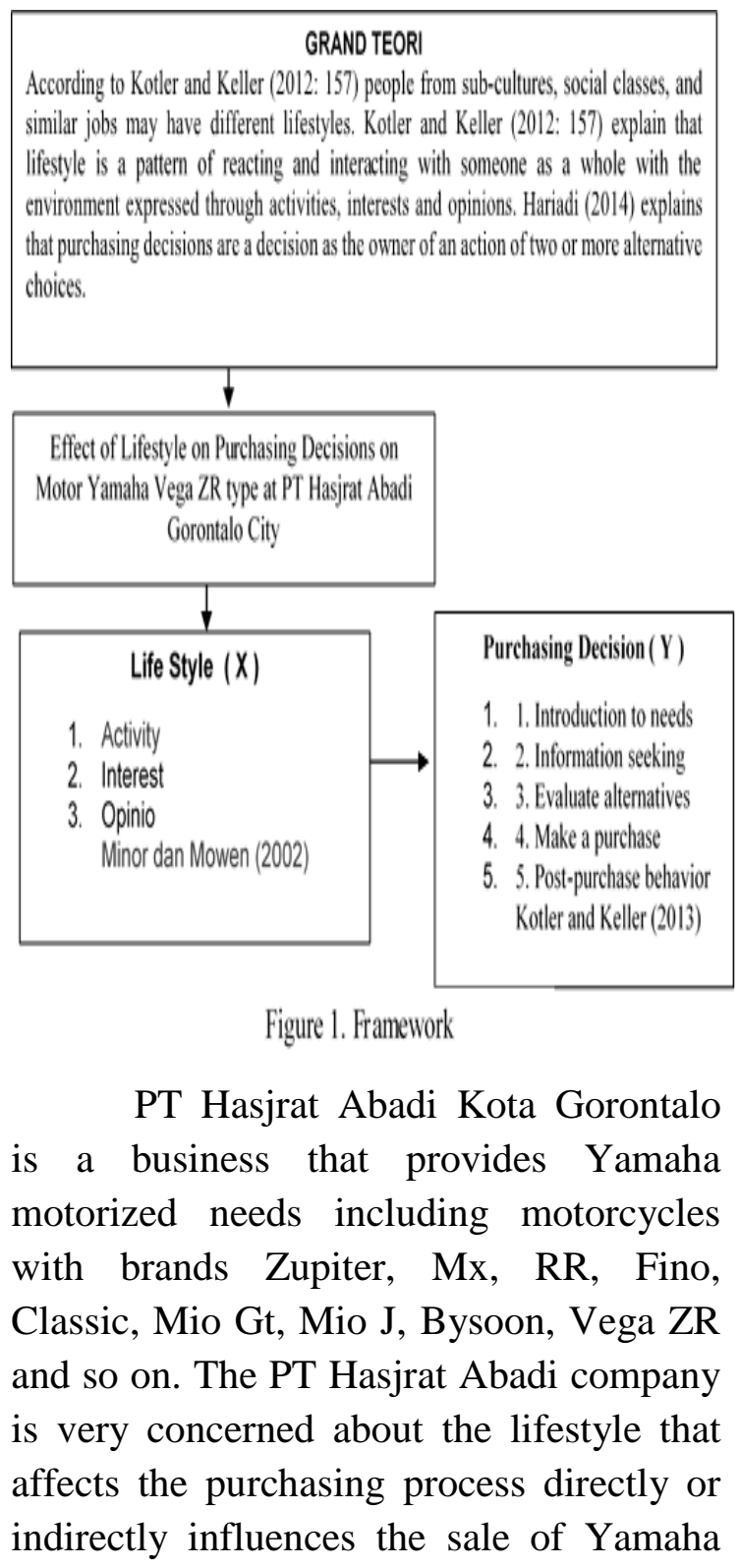


motorcycle products. Regarding purchasing decisions and lifestyle, this study was conducted at PT Hasjrat Abadi Gorontalo City. PT Hasjrat Abadi Gorontalo City is one of these companies selling various types of Yamaha motorcycle products with various types etc. Many marketing activities carried out by the company. However, in carrying out these marketing activities it cannot be said to be optimal. There are still many obstacles and problems faced in carrying out marketing activities. This is reflected in the results of sales obtained by PT Hasjrat Abadi Kota Gorontalo. The purpose of this study was to determine whether there was a lifestyle effect on the purchasing decision of the YAMAHA Vega ZR Motor at PT Hasjrat Abadi Gorontalo City.

\section{METHOD}

This research took place at PT. Hasjrat Abadi Gorontalo City, Ahmad Yani No.9A Gorontalo city. Data sources used primary data and secondary data. The design of this study uses a quantitative method, this is due to the research objectives that see how much influence lifestyle has on purchasing decisions. According to Sugiono (2013: 56) a causal relationship is a relationship that has a multiplicity of causes and effects where there are Independent variables (variables that are affected) and dependent variables (influenced) Independent variables used in this study are lifestyle, while the dependent variable used in this study namely the purchase decision, based on the description above, the design of this study can be described as follows.

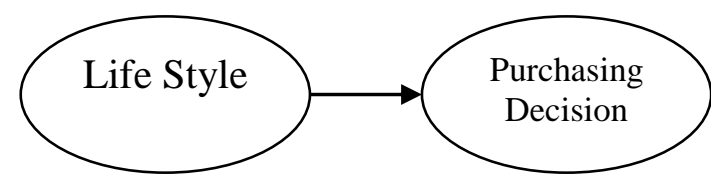

Figure 2. Research Design

The population referred to here is the total of the average consumers of PT Hasjrat Kota Gorontalo in 2016, 2017 and 2018. In applying the sample size (sample size). The sampling technique in this study is to use non-probability sampling technique that is non-probability sampling is a sample technique that provides equal opportunities for population elements to choose to become members of the sample, taking by purposive sampling. Data collection techniques through observation and questionnaires. The analysis technique uses simple linear regression analysis. Simple regression is based on functional or causal relationships of one independent variable with one dependent variable (Sugiono, 2013: 270).

\section{RESULTS AND DISCUSSION}

\section{Test Validity and Reliability}

Based on the results of the validity test, it shows that the questions in the lifestyle variable $(\mathrm{X})$ have a correlation coefficient greater than Rtable which is 0.359 in the one-way test with a significance level of 0.05 . Based on the statement an instrument is said to be valid if the minimum requirements are met, that is if the correlation coefficient is $>0.3$. So if the correlation between items with a 
total score of $<0.3$, the items in the instrument are declared invalid. Sugiyono (2014: 178), the test results show that the data tested in this test is said to be valid. The sample used in this test uses 20 samples outside of the sample 97 samples available. This test is done using a questionnaire that is distributed.

The reliability test in this study used the Croanbach's Alpa coefficient with the help of SPSS version 19. Reliability testing was shown by Alpha Croanbach coefficient and can be processed with the help of SPSS version 19. If there is a statement that Croanbach's Alpa value if item deleted is greater than Croanbach's Alpa then the statement not reliable and further testing must be done. The test results are said to be reliable if the Alpa Croanbach value is> 0.6 and the Alpa Croanbach value is greater than Croanbach's Alpa if item deleted (Sekaran, 2006: 182).

Table 1. Lifestyle Reliability Test Results (X)

\begin{tabular}{|r|r|}
\hline $\begin{array}{c}\text { Cronbach's } \\
\text { Alpha }\end{array}$ & $\begin{array}{c}\text { N of } \\
\text { Items }\end{array}$ \\
\hline .927 & 15 \\
\hline
\end{tabular}

Source: Data Processed

Lifestyle variable (X) with 15 question items shows the value of Cronbach's alpha0.927. The test results are said to be reliable if the Alpa Croanbach value is> 0.6 and the Alpa Croanbach value is greater than Croanbach's Alpa if item deleted (Sekaran, 2006: 182). Based on the statement, the data in this test are said to be reliable.

Table 2. Purchasing Decision Reliability Test Results (Y)

\begin{tabular}{|r|r|}
\hline $\begin{array}{c}\text { Cronbach's } \\
\text { Alpha }\end{array}$ & $\begin{array}{c}\text { N of } \\
\text { Items }\end{array}$ \\
\hline .943 & 15 \\
\hline
\end{tabular}

Source: Data Processed

Purchase Decision (Y) with 15 items of questions shows the value of Cronbach's alpha0.943. The test results are said to be reliable if the Alpa Croanbach value is> 0.6 and the Alpa Croanbach value is greater than Croanbach's Alpa if item deleted (Sekaran, 2006: 182). Based on the statement, the data in this test are said to be reliable.

\section{Normality test}

This test aims to test whether there is a regression model, the dependent variable and the independent variable have normal or near normal data distribution. We can see from the normal probality plot that forms a diagonal straight line, and plot the data to be compared with the diagonal line. Whether the data spreads around the diagonal line and follows the direction of the diagonal line on the histogram graph then shows the normal distribution pattern. Conversely if the data is far from the diagonal line or does not follow the direction of the diagonal line on the histogram graph, it shows an abnormal distribution pattern, according to Ghozali in marwadi (2014.223). 
Tabel 3. One-Sample Kolmogorov-Smirnov Test

\begin{tabular}{|c|c|c|c|}
\hline & & $\begin{array}{c}\text { Gayahidu } \\
\text { p }\end{array}$ & $\begin{array}{l}\text { Keputusanpe } \\
\text { mbelian }\end{array}$ \\
\hline \multirow{3}{*}{$\begin{array}{l}\text { Normal Parameters } \\
\text { No,b }\end{array}$} & & 97 & 97 \\
\hline & Mean & 59.7526 & 57.6907 \\
\hline & Std. Deviation & 6.40643 & 7.92854 \\
\hline Most Extreme & Absolute & .113 & .079 \\
\hline \multirow[t]{2}{*}{ Differences } & Positive & .113 & .079 \\
\hline & Negative & -.064 & -.068 \\
\hline \multicolumn{2}{|l|}{ Kolmogorov-Smirnov Z } & 1.117 & .778 \\
\hline \multicolumn{2}{|l|}{ Asymp. Sig. (2-tailed) } & .164 & .581 \\
\hline
\end{tabular}

\section{Source: Data Processed}

Based on the table above, it is known that the number of respondents (n) is 97. Then obtained Lifestyle Variable KS is 0.778 and the purchasing decision is 1.117 with a significant value of each variable of $0.164(\mathrm{X})$ and $0.581(\mathrm{Y})$ each variable has a value significantly greater than 0.05 , so it can be concluded that the processed data has been normally distributed, in other words the assumption of the normality of this research has been achieved. We can also see the normality test in the regression $p-p$ plot as follows: Figure 1. P-P Normality Test Results Plot

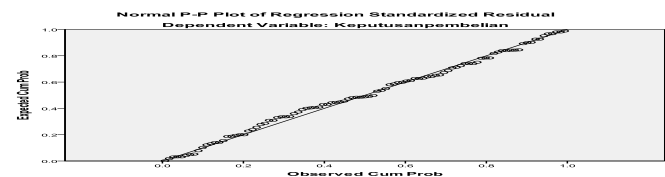

Based on the image of the regression analysis with the $\mathrm{p}-\mathrm{p}$ graph plot against the residuals above, it shows that the data forms a point that spreads not far from the diagonal line, meaning that the data is normally distributed.

\section{Simple Regression Analysis}

Simple regression is based on the functional or causal relationship of one independent variable with one dependent variable (Sugiono, 2013: 270).

Table 4. Results of Regression Analysis

Coefficients $^{\mathrm{a}}$

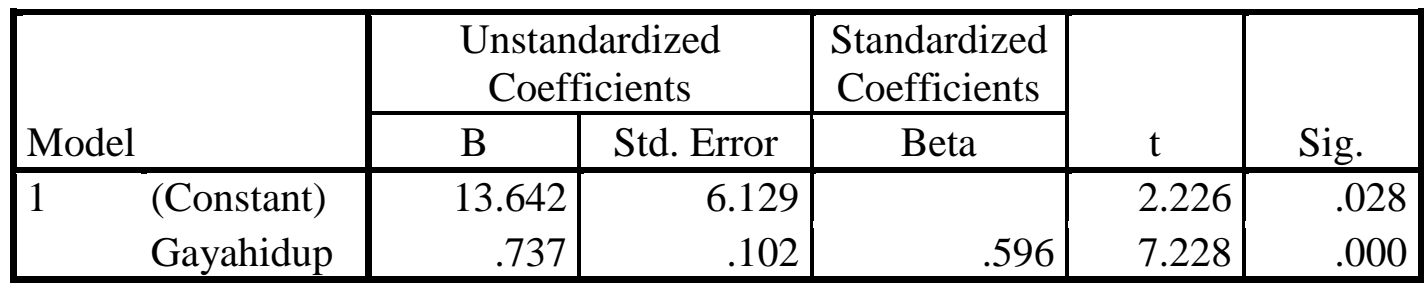

a. Dependent Variable: Purchasing decision

\section{Source: Data Processed}

Based on the above results it is known that the Constant $(\alpha)$ value is 13,642 while the Trust value (b/ regression coefficient) is
0.696 so the regression equation can be written:

$=\mathrm{a}+\mathrm{bX}=\mathrm{e}$ 
$\mathrm{Y}=13.642+0,737 \mathrm{X}+\mathrm{e}$

The equation can be translated as follows:

1. The constant of 13,642 means that the consistent value of the Lifestyle variable is 13,642 . This means that if there is no influence from the independent variable (Lifestyle) on the dependent variable (Purchasing Decision). Then obtained a value of 13,642 units per point Lifestyle.
2. The Lifestyle Regression Coefficient of 0.737 states that every addition of $1 \%$ of the Trust value, the Lifestyle value increases by 0.737 . The regression coefficient is positive, so it can be said that the direction of the influence of the independent variable Lifestyle on the Bound Purchase Decision variable is positive.

Table 5. t-test

Coefficients $^{\mathrm{a}}$

\begin{tabular}{|c|c|c|c|c|c|c|}
\hline \multirow{2}{*}{\multicolumn{2}{|c|}{ Model }} & \multicolumn{2}{|c|}{$\begin{array}{c}\text { Unstandardized } \\
\text { Coefficients }\end{array}$} & $\begin{array}{c}\text { Standardized } \\
\text { Coefficients }\end{array}$ & \multirow[b]{2}{*}{$\mathrm{t}$} & \multirow[b]{2}{*}{ Sig. } \\
\hline & & B & Std. Error & Beta & & \\
\hline & (Constant) & 13.642 & 6.129 & & 2.226 & .028 \\
\hline & Gayahidup & .737 & .102 & .596 & 7.228 & .000 \\
\hline
\end{tabular}

a. Dependent Variable: Purchasing decision

\section{Source: Data Processed}

1. If tcount $>\mathrm{t}$ table at the confidence level of $95 \%(\alpha=0.05)$, then it is evident that the lifestyle variable significantly influences the purchasing decision on consumers at PT Hasjrat Abadi Kota Gorontalo

2. If tcount $<\mathrm{t}$ table at the confidence level of $95 \%(\alpha=0.05)$, then it is evident that the lifestyle variable does not affect the purchasing decision at PT Hasjrat Abadi Kota Gorontalo

$\mathrm{t}$ table $=\mathrm{t}(\alpha / 1 ; \mathrm{n}-\mathrm{k}-1)=\mathrm{t}(0.05 ; 95)=$ 1.661

From the test results shown in table 4.13 , it can be concluded as follows: Know the value of Sig. for the influence of Lifestyle (Variable $\mathrm{X}$ ) is equal to $0,000<0.05$ and $\mathrm{t}$ Calculate 7,228> t table 1,661. Then the hypothesis $\mathrm{t}$ test for Ha (Lifestyle variable) is influential and the first hypothesis (Ha) can be proven or accepted. Thus testing the test hypothesis $\mathrm{t}$ for lifestyle variables have a positive effect with a tcount greater than ttable which means that lifestyle has a significant influence on purchasing decisions.

\section{Coefficient of Determination}

The function of the coefficient of determination (R2) is to measure how far the ability of the model in explaining 
variations in the dependent variable. The coefficient of determination is between 0 and 1. The small $\mathrm{R} 2$ value indicates the ability of the independent variable to explain the variation of the dependent variable which is very limited in Sanusi (2014: 120-121). According to Ghozali (2013: 220) A value close to one means that the independent variables provide almost all the information needed to predict variations in the dependent variable. The smaller the coefficient of determination means the ability of independent variables to explain variations in the dependent variable.

\section{Table 6. Coefficient of}

\section{Determination}

\section{Model Summary ${ }^{b}$}

\begin{tabular}{|l|c|r|r|r|}
\hline Model & $\mathrm{R}$ & $\begin{array}{c}\mathrm{R} \\
\text { Square }\end{array}$ & $\begin{array}{l}\text { Adjusted } \\
\text { R Square }\end{array}$ & $\begin{array}{l}\text { Std. Error of } \\
\text { the Estimate }\end{array}$ \\
\hline 1 & $.596^{\mathrm{a}}$ & .355 & .348 & 6.40189 \\
\hline
\end{tabular}

a. Predictors: (Constant), Life style

b. Dependent Variable: Purchasing decision

\section{Source: Data Processed}

Based on the table of analysis the coefficient of determination above shows the magnitude of the correlation coefficient has a value of $R$ which is equal to 0.596 in other words having a strong relationship. for the $\mathrm{R}$ Square value of 0.355 . This shows that $35.5 \%$ of the independent variable $\mathrm{X}$ (Lifestyle) contributes to influencing the $\mathrm{Y}$ variable (Purchase Decision), and the remaining balance is 0.645 or $64.5 \%$ in the form of contributions from other factors or indicators not included or measured and examined in this study for example such as promotion, price, brand image and so on.

\section{Discussion}

Some research on lifestyle found that lifestyle as a factor that is closer to reflecting interests and value values of consumers who continue to experience change and ultimately that value will affect their behavior. According to Kotler (2009: 105) as for factors that influence consumer purchasing decisions consist of age and life cycle stages, work and economic environment, lifestyle, personality and self-concept. The choice of product is greatly influenced by one's economic situation. Seeing the statement stated by Kotler is in line with the phenomenon that occurs considering consumers who have different ages, different income, personality etc. The lifestyle that is owned by each person (consumer) PT. Eternal Empowerment classified in the criteria of "Good" we can see in the phenomenon seen in consumers PT. Hasanjrat Abadi can be seen based on the descriptive of $59.68 \%$. Lifestyle can also be used as a benchmark to see the lifestyle of existing consumers.

This research was conducted at PT Hasjrat Abadi Gorontalo City. Regarding the purchasing decisions and lifestyle of consumers, PT Hasjrat Abadi is one company that sells various motorbikes. The decision to buy a Yamaha motorcycle type Vega ZR at PT. Hasanjrat Abadi from the data obtained that the sale of these motorcycles has decreased, this was 
caused due to the quality or design of the motorbike or even the increasingly rapid development of the times. This is a reference for PT.Hasjrat Abadi to reevaluate what will be a suggestion or improvement in the quality of a Yamaha motorcycle type Vega ZR. Yamaha motorbike purchasing decisions fall into the criteria of "good", where it can be seen from the results of the tabulation of the answers to the distributed questionnaire. conducted with descriptive results of research that resulted in a purchase decision on the PT. Hasjrat Abadi amounting to $57.82 \%$.

Consumer lifestyle in good category. Where, PT Hasjrat Abadi provides needs that are in accordance with the wishes of consumers so that the efforts made can increase consumer purchasing decisions at PT Hasjrat Abadi Gorontalo City. It can be concluded that $\mathrm{H} 1$ is accepted and Ho is rejected, meaning lifestyle significantly influences the purchasing decision at PT Hasjrat Abadi Gorontalo City. It can be concluded that the hypothesis submitted by the author is stated to be proven (real) and this is in accordance with the results of previous research conducted by Nurul Almi (2016) showing simultaneously the influence of lifestyle on purchasing decisions is significant.

The most influential lifestyle variable indicators are interest indicators with validity levels ranging from 0.883 0.913. and for the most influential purchasing decision variable indicators are alternative evaluation indicators with validity levels $0.599-0.913$. Based on the results of the study for the decline of the vega motor zr because the need to use a motorcycle is very low in terms of work or activity because the motorbike is only used to go to the mountain because some of them think that the motorbike is more suitable to use when gardening, long trips due to quality the engine is very guaranteed. And with the growing era with many of the latest innovations produced for the development of motorbikes that have more high quality and attract the attention of consumers to buy because of the design and models that can make consumers confident when using the motorcycle. For example, at this time, the bomming of N-Max motorbikes is now again. And more interested in metic motors because it is more simple and comfortable to drive.

\section{CONCLUSION}

Based on the results of research and data analysis, it shows that lifestyle variables have a significant influence on decisions. The results of the determination test show that $35.5 \%$ of the independent variable (lifestyle) and have a contribution to influence purchasing decisions at PT Hasjrat Abadi Gorontalo. Whereas 64\% allows to be influenced by other factors (variables) such as promotion, quality, attitude, motivation and so on. In the results of this study for the most influential lifestyle variable indicators are indicators of interest (interest) with a validity level ranging from 0.883 to 0.913 . and for the 
most influential purchasing decision variable the alternative evaluation indicator is the validity level of 0.599 0.913 .

\section{SUGGESTION}

Based on the conclusions above, the researcher suggests;

1. It is recommended that the leaders of PT Hasjrat Abadi Gorontalo city pay more attention to consumer lifestyles, for example from various motor designs, motorbike brand images and promotions. In addition, they should pay more attention to the lack of products with the latest models so that consumers are more interested in buying a new motorbike at PT Hasjrat Abadi Gorontalo City.

2. For further researchers, it is expected to be able to expand the location of research and add other research variables such as motivation, attitudes, brand image, product quality to purchasing decisions.

\section{REFERENCES}

Almi, Nuruli. 2012 The influence of lifestyle to the purchase decision of kawasaki ninja bikes Pekan Baru.

Drucker, petter,F Manajemen: tugas, tanggung jawab dan praktek Jakarta PT Gramedia.

Ferdiand, Augusty 2006 Metode penelitian manajemen: pedoman penelitian untuk penulisan skripsi, tesis dan desertasi ilmu manajemen: bahan penerbit

universitas

dipanegoro,Semarang.

Fandy Tjiptono.2012. service managemen

Pemasaran mewujudkan layanan prima ,CV andi offset,yogjakarta.

Ghozali, Imam. 2013. Aplikasi Analisis Multivariate Dengan Program SPSS. Cetakan Keempat. Semarang: Badan Penerbit Universitas Diponegoro.

John C. Mowen, Michael Minor. 2002, Perilaku konsumen (jilid 1), Edisi kelima,Erlangga, Jakarta, Hal 312.

Kasali, Rhenald.2013.Membidik

Pasar Indonesia: Segmenting,

Targeting dan Positioning. Jakarta:

PT Gramedia Pustaka Utama.

Keller, Kevin,. 2013. Strategic Brand

Management, Building

Measurement and Managing Brand Equity, Upper Sadle River, NJ Person Education Internasional.

Kotler, p. \& Amstrong G. 2013. Prinsip-

Prinsip Pemasaran. Edisi ke 12 ,jilld 2, edisi ke 8,terjemahan. Bob Sabran. Jakarta: Erlangga.

Kotler, philip dan kevin lane keller 2010, manajemen pemasaran. Jakarta, Penerbit Erlangga.

Ridhwan, Ria Maharani, 2014, "Pengaruh Citra Merek Sepatu Nike terhadap Keputusan Pembelian" Jakarta.

Ridwan, Akdon. 2007, Rumus dan Data dalam analisis data, edisi 2, Jilid I, Bandung : Alfabeta.

Sugiono, (2013), Metode Penelitian Bisnis, Penerbit Alfabeta, Bandung. Sunarto, Komanto, 2011; Pengantar Sosiologi, Edisi Kedua, Jakarta: 
Lembaga Penerbit Fakultas ekonomi.

Tjiptono, Fandy. (2013). Strategi Pemasaran. Yogyakarta, Penerbit Andi

Saraputra, Widya 2017.Pengaruh gaya hidup terhadap niat pembelian sepeda motor sport honda yang di dmensi oleh sikap.

Tjiptono, fandy dan greagorius Chandra 2012, pemasaran strategic, Jogjakarta
Stanton, Ari, Putra 2013.pengaruh gaya hidup dan harga terhadap keputusan pembelian.

Schifrrman, Kanuk 2006 Metode penelitian manajemen: pedoman penelitian untuk penulisan skripsi, tesis dan desertasi ilmu manajemen: bahan penerbit universitas dipanegoro, Semarang.

Widjaya 2013. pengaruh gaya hidup dan harga terhadap keputusan pembelian 